\title{
The Occupational Burnout among Therapeutic Employees of Hospitals in Iran by the Kind of Ownership
}

\author{
Ghahraman Mahmoudi ${ }^{1}$, Mohammad Ali Jahani², Masoomeh Abdi' ${ }^{3}$, Sedigheh Solimanian², \\ Hossein Ali Nikbakht², Soheil Ebrahimpour ${ }^{4}$ \\ ${ }^{1}$ Hospital Administration Research Center, Sari Branch, Islamic Azad University, Sari, I.R Iran \\ ${ }^{2}$ Social Determinants of Health Research Center, Health Research Institute, \\ Babol University of Medical Sciences, Babol, I.R.Iran \\ ${ }^{3}$ Mazandaran University of Medical Sciences, Sari, I R Iran \\ ${ }^{4}$ Infectious Diseases and Tropical Medicine Research Center, Health Research Institute, \\ Babol University of Medical Sciences, Babol, I.R. Iran
}

SUMMARY

As a complex and multidimensional problem, the occupational burnout causes absence, dissatisfaction, badtemper, physical and emotional exhaustion and displacement. This study aimed to investigate the levels of occupational burnout and its components in Mazandaran's hospitals by the kind of their ownership. This descriptive-analytical study was conducted as a cross-sectional research in 2018. The research population included all 2,850 therapeutic employees working in two teaching hospitals, one therapeutic hospital, one social security hospital and one private hospital, all located in Mazandaran province, Iran. In total, 569 questionnaires were completed; the research instrument was the Persianversion of Maslach Burnout Inventory (MBI). Data were analyzed in SPSS 22 by applying statistical approaches with $\mathrm{p}<0.05$. The private hospital had the highest mean rate of emotional exhaustion (44.69 \pm 8.50). The social security hospital had the highest mean rate of depersonalization $(25.47 \pm 4.59)$. Considering the reduced personal accomplishment, as a component, the private hospital had the highest rate $(30.24 \pm 7.16)$. The highest and lowest mean rates of occupational burnout were observed with the private hospital $(95.48 \pm 16.71)$ and teaching hospitals $(85.25 \pm 15.34)$. The difference was significant between the studied hospitals in this regard $(p<0.001)$. As the private hospital had a higher rate of occupational burnout than therapeutic, teaching, and social security hospitals, the managers of the private hospital can focus on removing various tensions in the workplace and preventing heavy work length as well as compensating for a pay decrease.

Key words: occupational burnout, ownership, therapeutic employees, Mazandaran province, Iran

Corresponding author:

Mohammad Ali Jahani

e-mail: drmajahani@gmail.com 


\section{INTRODUCTION}

As one of the main risk factors, the occupational burnout $(\mathrm{OB})$ is more common in serviceproviding jobs $(1,2)$. It is a physical-mental syndrome with extreme tiredness that results in negative attitudes and behavior towards self, others and customers, but also in unproductive work, absence, work dissatisfaction, ineffectiveness, work displacement and unethical behavior (3). Coined by Freudenberger in 1974, occupational burnout includes three dimensions: emotional exhaustion, depersonalization disorder and personal inefficacy or nonachievement (4). Emotional exhaustion refers to one's mental stress and a sense of emotional pressure. Depersonalization points to negative attitudes towards others, whereas personal non-achievement refers to one's impression of inefficacy and nonachievement in performing their job responsibilities (5). Therapeutic employees in hospitals stand for valuable staff and human capital in the healthcare (6); they maintain a close relations with the public and thus have a great health-related responsibility. A continuous encounter with suffering patients, incurable diseases and unexpected deaths make therapy jobs as stressful ones (7). For example, occupational burnout is common among $30-50 \%$ of nursing staff (8), resulting in increased absence, decreased energy, low efficacy, and low-quality service to patients (9). A study showed that the estimated cost of burnout in the USA annually amounts to 50 - 70 million \$ (10) and its rate among healthcare staff is high up to 43 $50 \%$ (11). As burnout decreases service quality and patients' satisfaction, it wastes the time and resources of the hospital and the patient (12). However, social support can decrease the staff's burnouts in organizations of various kinds (13). In addition, Hooper and colleagues found that nursing staff has a high rate of burnouts (14). Lang showed that the rate of burnout in the dimension 'emotional exhaustion' was the highest among nurses working in the clinical units of military hospitals in the USA (15). High rates of burnout were shown among medical faculty members in the US medical science universities (16).

Organizational development necessitates having healthy and efficient human resources without any burnouts. Occupational burnout in the health sector is one of the main concerns health sector managers and local health ministers have. This study aimed to investigate the levels of occupational burn- outs and its components in Mazandaran's selected hospitals by the kind of their ownership.

\section{PARTICIPANTS AND METHODS}

This descriptive-analytical study was conducted as a cross-sectional research in 2018. Research setting included two teaching hospitals, one therapeutic hospital, one social security hospital, and one private hospital, all located in Mazandaran province, Iran. Primarily, the study received ethical approval from the Institutional Review Board of College of Islamic Azad University (IR.IAUSARI. REC.1396.72). The research population included all 2,850 therapeutic employees working in midwifery, nursing, laboratory, and radiology units. Of them, 340 employees were selected randomly and proportionally by using Cochran's sampling formula. For more generalizability, 600 questionnaires were distributed among them, and 569 questionnaires were completed and analyzed. The research instrument was a two-part questionnaire including demographic variables (such as gender, age, marital status, working length, and working hospital name) in the first part and Maslach Burnout Inventory (MBI) with 22 items in 7 pointed Likert-type scale in the second part (17). The MBI measures three dimensions of occupational burnout: emotional exhaustion (items 1, 2, 3, 6, 8, 13, 14, 16, 20), depersonalization (items $5,10,11,15,22$ ), and reduced personal accomplishment (items 4, 7, 9, 12, 17, 18, 19, 21). The internal consistency of the Persian version of the scale was $\alpha=0.91$ (18). Collected data were analyzed in SPSS 21, with assuming the normality of distribution; the means and SDs of the quantitative variables were measured and the frequencies and percentages of the qualitative ones were reported. In the confidence interval of $95 \%$, independent t-test was used for comparing the two means. With assuming variance equalities, the one-way ANOVA was used for comparing the means of more than two components, as well as Tukey HSD for post-hoc test.

\section{RESULTS}

Of 569 subjects, $78.2 \%$ were female. The mean \pm SD of the age range of most subjects was $35.84 \pm 6.22$ years old (in the range of $24-58$ years old). The mean rate of employees' working length was $10.87 \pm 5.78$ in the range of 1 - 35 years. In addition, 469 (82.4\%) ones 
Table 1. Demographic information of the studied hospital employees

\begin{tabular}{|c|c|c|c|c|}
\hline Variable & Group & $\begin{array}{c}\text { Frequency } \\
(\%)\end{array}$ & $\begin{array}{c}\text { Burnout } \\
(\text { Mean } \pm S D)\end{array}$ & P-value \\
\hline \multirow[t]{2}{*}{ Gender } & Men & $124(21.8)$ & $87.83 \pm 17.69$ & \multirow[b]{2}{*}{0.865} \\
\hline & Women & $445(78.2)$ & $87.54 \pm 16.37$ & \\
\hline \multirow{3}{*}{ Educational level } & Diploma & $7(1.2)$ & $82.71 \pm 20.03$ & \multirow{3}{*}{0.672} \\
\hline & Bachelor of Science & $52(9.1)$ & $88.62 \pm 17.52$ & \\
\hline & Doctor of medicine and higher & $510(89.6)$ & $87.57 \pm 16.53$ & \\
\hline \multirow{2}{*}{ Marital status } & Unmarried & $100(17.6)$ & $87.22 \pm 18.56$ & \multirow[b]{2}{*}{0.799} \\
\hline & Married & $469(82.4)$ & $87.69 \pm 16.23$ & \\
\hline \multirow{3}{*}{ Employment } & Full-time & $275(48.3)$ & $86.55 \pm 16.84$ & \multirow{3}{*}{0.314} \\
\hline & Partial-time & $255(44.8)$ & $88.44 \pm 17.02$ & \\
\hline & Half-time & $39(6.9)$ & $89.64 \pm 12.00$ & \\
\hline \multirow{4}{*}{ Special job } & Nurse & $377(66.3)$ & $86.76 \pm 16.95$ & \multirow{4}{*}{0.057} \\
\hline & Midwife & $70(12.3)$ & $90.94 \pm 14.90$ & \\
\hline & Radiologist & $52(9.1)$ & $91.58 \pm 14.98$ & \\
\hline & Laboratory staff & $70(12.3)$ & $85.86 \pm 17.27$ & \\
\hline
\end{tabular}

Table 2. The mean \pm SD of occupational burnout and its components in the studied hospitals by the kind of their ownership

\begin{tabular}{c|c|c|c|c|c|l|l|l}
\hline \hline Variable & $\begin{array}{c}\text { Emotional } \\
\text { exhaustion }\end{array}$ & $\begin{array}{l}\text { Deperson- } \\
\text { alization }\end{array}$ & $\begin{array}{c}\text { Reduced } \\
\text { personal } \\
\text { accomplishment }\end{array}$ & $\begin{array}{l}\text { Occupational } \\
\text { Burnout }\end{array}$ & $\mathbf{9 5 \% \text { CI }}$ & Min. & Max. & F \\
\hline Therapeutic & $37.59 \pm 10.39$ & $22.84 \pm 5.36$ & $29.27 \pm 7.22$ & $85.63 \pm 18.70$ & $82.29-88.97$ & 46 & 116 & \\
\hline Private & $44.69 \pm 8.50$ & $25.19 \pm 4.87$ & $30.24 \pm 7.16$ & $95.48 \pm 16.71$ & $91.76-99.19$ & 42 & 118 \\
\hline Teaching & $38.90 \pm 9.77$ & $23.14 \pm 4.36$ & $27.40 \pm 6.98$ & $85.25 \pm 15.34$ & $83.40-87.10$ & 19 & 116 & 9.401 \\
\hline $\begin{array}{c}\text { Social } \\
\text { security }\end{array}$ & $41.28 \pm 8.77$ & $25.47 \pm 4.59$ & $28.05 \pm 6.91$ & $90.01 \pm 15.18$ & $87.00-93.02$ & 49 & 126 & \\
\hline \hline
\end{tabular}

were married. The mean rates of men and women's occupational burnout were $87.83 \pm 17.69$ and $87.54 \pm$ 16.37 , respectively. The difference in these mean rates was not significant $(p=0.865)$ (Table 1$)$. Table 2 shows the mean rates of occupational burnout and its components in the studied hospitals by the kind of their ownership. The private hospital had the highest mean rate of emotional exhaustion $(44.69 \pm 8.50)$. The social security hospital had the highest mean rate of depersonalization $(25.47 \pm 4.59)$. Regarding the reduced personal accomplishment, as a component, the private hospital again had the highest rate $(30.24 \pm$ 7.16). The highest and lowest mean rates of the occupational burnout were observed for the private hospital $(95.48 \pm 16.71)$ and teaching hospitals $(85.25 \pm$ 15.34). The difference was statistically significant among the hospitals $(\mathrm{p}<0.001)$. Table 3 shows that the private hospital had the highest mean rate of emotional exhaustion. In two-by-two comparison, it appeared that the private hospital had 7.10 and 5.78 units more than the therapeutic hospital and the teaching hospitals, respectively. The differences were significant in this regard $(\mathrm{p}<0.001)$. While the private hospital had a higher mean rate than that of the social security one (with 3.40 units), the difference was not statistically significant $(p=0.084)$. In other hospitals, only the social security hospital had 3.69 units more than that of the therapeutic one which was significantly different, too $(\mathrm{p}<0.05)$.

In the component depersonalization, the higher rate was seen for the private hospital and the social security hospital. The private hospital had 2.35 and 2.04 units more than the therapeutic hospital and the teaching hospitals, respectively. The social security hospital had 2.63 and 2.33 units more than the therapeutic hospital and the teaching hospitals, 
respectively. All of the differences were statistically significant $(p<0.05)$. In the component reduced personal accomplishment, the highest mean rate belonged to the private hospital. This hospital had 2.83 units more than that of the teaching hospitals $(\mathrm{p}=$ 0.009). In other hospitals, the therapeutic hospital had 1.86 units more than that of the teaching hospital, which was not statistically significant $(p=0.073)$.
Table 4 shows the relationship between the components of occupational burnout and employees' gender in the studied hospitals. Despite relative differences in the mean rates of the components emotional exhaustion and depersonalization in favor of men and that of reduced personal accomplishment in favor of women, the differences were not statistically significant from a gender perspective.

Table 3. The relationships among the components of occupational burnout in the studied hospitals by the kind of their ownership

\begin{tabular}{|c|c|c|c|c|c|}
\hline Components & $\begin{array}{c}\text { Kind of hospital } \\
\text { ownership }\end{array}$ & MD & $95 \%$ CI & p-value & p-value \\
\hline \multirow{6}{*}{$\begin{array}{l}\text { Emotional } \\
\text { exhaustion }\end{array}$} & Therapeutic-private & -7.10 & -10.65 to -3.56 & 0.000 & \multirow{6}{*}{0.00} \\
\hline & Therapeutic-teaching & -1.31 & -4.00 to 1.38 & 0.590 & \\
\hline & $\begin{array}{c}\text { Therapeutic-social } \\
\text { secure }\end{array}$ & -3.69 & -7.02 to -0.37 & 0.022 & \\
\hline & Private-teaching & 5.78 & 2.64 to 8.94 & 0.000 & \\
\hline & Private-social security & 3.40 & -0.29 to 7.11 & 0.084 & \\
\hline & Teaching-social security & -2.38 & -5.28 to 0.51 & 0.148 & \\
\hline \multirow{6}{*}{ Depersonalization } & Therapeutic-private & -2.35 & -4.09 to -0.61 & 0.003 & \multirow{6}{*}{0.000} \\
\hline & Therapeutic-teaching & -0.30 & -1.62 to 1.02 & 0.936 & \\
\hline & $\begin{array}{c}\text { Therapeutic-social } \\
\text { secure }\end{array}$ & -2.63 & -4.27 to -1.00 & 0.000 & \\
\hline & Private-teaching & 2.04 & 0.5 to 3.60 & 0.004 & \\
\hline & Private-social security & -0.28 & -2.10 to 1.54 & 0.978 & \\
\hline & Teaching-social security & -2.33 & -3.75 to -0.91 & 0.000 & \\
\hline \multirow{6}{*}{$\begin{array}{l}\text { Reduced personal } \\
\text { accomplishment }\end{array}$} & Therapeutic-private & -0.96 & -3.58 to 1.64 & 0.774 & \multirow{6}{*}{0.005} \\
\hline & Therapeutic-teaching & 1.86 & -0.12 to 3.85 & 0.073 & \\
\hline & $\begin{array}{l}\text { Therapeutic-social } \\
\text { secure }\end{array}$ & 1.21 & -1.23 to 3.66 & 0.574 & \\
\hline & Private-teaching & 2.83 & 0.52 to 5.15 & 0.009 & \\
\hline & Private-social security & 2.18 & -0.54 to 4.91 & 0.165 & \\
\hline & Teaching-social security & -0.64 & -2.78 to 1.48 & 0.862 & \\
\hline
\end{tabular}

Table 4. The relationships between the components of occupational burnout and employees' gender in the studied hospitals

\begin{tabular}{c|c|c|c|c|c}
\hline \hline Components & $\begin{array}{c}\text { Mean } \pm \text { SD } \\
\text { (men) }\end{array}$ & $\begin{array}{c}\text { Mean } \pm \text { SD } \\
\text { (women) }\end{array}$ & MD* & 95\% CI & p-value \\
\hline $\begin{array}{c}\text { Emotional } \\
\text { exhaustion }\end{array}$ & $40.55 \pm 9.46$ & $39.65 \pm 9.91$ & 0.897 & -1.06 to 2.85 & 0.369 \\
\hline Depersonalization & $23.90 \pm 5.00$ & $23.74 \pm 4.7$ & 0.158 & -.80 to 1.12 & 0.747 \\
\hline $\begin{array}{c}\text { Reduced personal } \\
\text { accomplishment }\end{array}$ & $27.81 \pm 8.05$ & $28.46 \pm 6.83$ & -0.64 & -2.06 to .77 & 0.373 \\
\hline \hline
\end{tabular}




\section{DISCUSSION}

The findings showed that the highest and the least mean rates of occupational burnout among the employees working in the studied hospitals were observed for private hospital and the teaching hospitals, respectively. The difference was statistically significant in the studied hospitals. The highest mean rate belonged to the private hospital in the component emotional exhaustion, to the social security hospital in the component depersonalization, and to the private hospital again in the component reduced personal accomplishment. One study showed a higher mean rate of occupational burnout among nursing staff working in teaching hospitals (19). In Singapore hospitals, $39 \%, 40 \%$ and $59 \%$ of the nursing staff had high emotional exhaustion, depersonalization and reduced personal accomplishment, respectively (20). The private hospital has the highest rate of employees' emotional exhaustion. Such a finding was reported among Jordanian nurses (21), and among the employees of the US military hospitals (15). Raftopouls and colleagues found a similar rate of high emotional exhaustion as well as that of depersonalization in the public and private hospitals (22). The emotional exhaustion results in a decrease in individuals' energy and working motivation and increase in their exhaustion. As some inexperienced personnel may be employed in private hospitals or some retirees from public hospitals who still want to work, however, under inappropriate working circumstances and with low income, the private hospitals may have employees without enough work motivation. The private hospital had the highest mean rate of reduced personal accomplishment. In Australian governmental hospitals, the highest rate of reduced personal and occupational accomplishment was reported (23). Jafari-Iraqi et al. reported the highest rate of reduced personal achievement among nursing staff in a military hospital (24). The possible reasons for the finding are that the private nature of the private hospital results in major obstacles to its personal achievement, involved in low standards of human resources and high job pressure as well as more focus on profit from services. Occupational burnout syndrome among various medical groups causes low performance, decreased self-efficacy and low-quality services and consequent insufficient treatment of patients (25). The highest mean rate of depersonal- ization belonged to the social security hospital. Abualrub et al. found that Abualrub nursing staff in private hospitals had higher rates of job satisfaction than the ones working in governmental hospitals (26). In the study on the occupational burnout of employees working in the emergency care sections in Greece, the rate of occupational burnout was at a moderate level with the highest rate in depersonalization (27). Mooghali et al. found a high rate of component depersonalization in private hospitals (28). Habibi et al. reported the same in the governmental health section (28). It can be argued that the high volume of patients refers to the social security hospitals and their expectancy of rapid service giving results in double pressure to the staff working in the hospitals of this kind. Findings also show that emotional exhaustion and depersonalization were higher among men than women. The reduced personal accomplishment was higher among women than men. However, the differences were not statistically significant. Lahana et al. found the highest rate of emotional exhaustion, depersonalization, and non-accomplishment among men (29). Pantenburg found a high degree of emotional exhaustion among men (30). However, Raftopouls et al. found a higher rate of emotional exhaustion in women $(93 \%)$ than men $(87.5 \%)$ (22). Others studies showed that the emotional exhaustion among women was more than that in men in the health care (31, 32) as well as the working population (33). It appears that the workplace had the main role in the occupational burnout. Perhaps, the mandatory orders and imposing hard works on men are at work in their increased job stress and consequent emotional exhaustion. One of the main limitations of the study is that possibly different findings may be found in other regions of the country; one other limitation of the study was the deficiencies in the related literature on the topic in the healthcare sector.

\section{CONCLUSION}

As the private hospital had higher rate of occupational burnout than that of therapeutic, teaching, and social security hospitals, it can be proposed that the managers of the private hospital focus on removing various tensions in the workplace, preventing heavy work load and length and compensating for a pay decrease. 


\section{Conflict of interests} authors.
No conflict of interest was declared by the

\section{Acknowledgement}

Authors thank all the employees working in the studied hospitals for their participation in the study and for their opinions on better conducting the research.

\section{References}

1. Garrosa E, Moreno-Jimenez B, Liang Y, Gonzalez JL. The relationship between socio-demographic variables, job stressors, burnout, and hardy personality in nurses: An exploratory study. Int J Nurs Stud 2008;45:418-27. https://doi.org/10.1371/journal.pone.0157013

2. Zhou J, Yang Y, Qiu X, et al. Relationship between anxiety and burnout among Chinese physicians: a moderated mediation model. PloS One 2016;11:e0157013.

https://doi.org/10.1016/j.ijnurstu.2006.09.003

3. Kotb AA, Mohamed KA-E, Kamel MH, Ismail MAR, Abdulmajeed AA. Comparison of burnout pattern between hospital physicians and family physicians working in Suez Canal University Hospitals. Pan Afr Med J 2014;18:164-74. https://doi.org/10.11604/pamj.2014.18.164.3355

4. Teixeira C, Ribeiro O, Fonseca AM, Carvalho AS. Burnout in intensive care units-a consideration of the possible prevalence and frequency of new risk factors: a descriptive correlational multicentre study. BMC Anesthesiol 2013;13:38-52.

doi: 10.1186/1471-2253-13-38

https://doi.org/10.1186/1471-2253-13-38

5. Wilson W, Raj JP, Narayan G, Ghiya M, Murty S, Joseph B. Quantifying burnout among emergency medicine professionals. J Emerg Trauma Shock 2017;10:199-204.

\section{https://doi.org/10.4103/JETS.JETS 3617}

6. Niazi S, Jahani M, Mahmoodi G. Evaluation of human resources in the hospitals affiliated to babol university of medical sciences and social security of qaemshahr city based on the standards of the Iranian ministry of health. JBUMS 2016;18:56-63. (In Persian)

7. Emold C, Schneider N, Meller I, Yagil Y. Communication skills, working environment and burnout among oncology nurses. Eur J Oncol Nurs 2011;15:358-63.

https://doi.org/10.1016/j.ejon.2010.08.001

8. Poncet MC, Toullic P, Papazian L, et al. Burnout syndrome in critical care nursing staff. Am J Respir Crit Care Med 2007;175:698-704.

https://doi.org/10.1164/rccm.200606-806OC

9. Burgess L, Irvine F, Wallymahmed A. Personality, stress and coping in intensive care nurses: a descriptive exploratory study. Nurs Crit Care 2010;15:129-40.

https://doi.org/10.1111/j.1478-5153.2009.00384.x

10. Darban F, Balouchi A, Narouipour A, Safarzaei E, Shahdadi $H$. Effect of communication skills training on the burnout of nurses: a crosssectional study. J Clin Diagn Res 2016;10:IC01-IC4. https://doi.org/10.7860/JCDR/2016/19312.7667 
11. Biksegn A, Kenfe T, Matiwos S, Eshetu G. Burnout Status at Work among Health Care Professionals in aTertiary Hospital. Ethiop J Health Sci 2016;26:101-8. PMC4864338 https://doi.org/10.4314/ejhs.v26i2.3

12. Stewart KL. Nurse managers' knowledge of staff nurse burnout: Western Carolina University; 2009. Availeable at: https://search.proquest.com/openview/cc075d2644 0c819e46256ee629945113

13. Lin C. Culture shock and social support: An investigation of a Chinese student organization on a US campus. J Intercult Commun Res 2006;35:117-37.

https://doi.org/10.1080/17475750600909279

14. Hooper C, Craig J, Janvrin DR, Wetsel MA, Reimels E. Compassion satisfaction, burnout, and compassion fatigue among emergency nurses compared with nurses in other selected inpatient specialties. J Emerg Nurs 2010;36:420-7. https://doi.org/10.1016/j.jen.2009.11.027

15. Lang GM, Patrician P, Steele N. Comparison of nurse burnout across Army hospital practice environments.J Nurs Scholarsh 2012;44:274-83. https://doi.org/10.1111/j.1547-5069.2012.01462.x

16. Shanafelt TD, Boone $S$, Tan $L$, et al. Burnout and satisfaction with work-life balance among US physicians relative to the general US population. Arch Intern Med 2012;172:1377-85.

https://doi.org/10.1001/archinternmed.2012.3199

17. Maslach C, Jackson SE, Leiter MP, Schaufeli WB, Schwab RL. Maslach burnout inventory: Consulting Psychologists Press Palo Alto, CA; 1986.

18. Haji MHM, Ghanbari AL, Aliakbarzade AZ, Abdi $M$. Mental health and job burnout among prehospital emergency care personnel. Emerg Disast Quart 2017;2:89-94.

https://doi.org/10.18869/nrip.hdq.2.2.89

19. Aaziz Nejad P, Hosseini S. Occupational Burnout and its causes, among practicing nurses in hospitals affiliated to Babol University of Medical Sciences. JBUMS 2004;8:63-9. ( In Persian)
20. Ang SY, Dhaliwal SS, Ayre TC, et al. Demographics and personality factors associated with burnout among nurses in a Singapore tertiary hospital. BioMed Res Intern 2016;2016:6960184. https://doi.org/10.1155/2016/6960184

21. Mudallal RH, Othman WaM, Al Hassan NF. Nurses' Burnout: The Influence of Leader Empowering Behaviors, Work Conditions, and Demographic Traits. J Health Care Org Prov Financ 2017;54:1-10. https://doi.org/10.1177/0046958017724944

22. Raftopoulos V, Charalambous A, Talias M. The factors associated with the burnout syndrome and fatigue in Cypriot nurses: a census report. BMC Public Health 2012;12:457-69. https://doi.org/10.1186/1471-2458-12-457

23. Marofi M, Mousaviasl F, Hemati Z. The Relationship Between Burnout and Quality of Work Life in Pediatric and Neonatal Intensive Care Unit Nurses. Iranian J Pediatr Nurs 2016;3:9-14. https://doi.org/10.21859/jpen-0301151

24. Iraqi IJ, Mahmoudi H, Nir MS, Ebadi A. Burnout in military hospital nurses in 2015-a cross-sectional study. J Milit Med 2016;18:262-70. (in Persian)

25. Pavlova J, Afanasieva L, Deliyska B. Economic dimensions of burnout among medical professionals in Bulgaria. J Manag Market Healthcare 2011;4:247-53. https://doi.org/10.1179/1753304X11Y.0000000011

26. Abualrub RF, Omari FH, AL RUB A, FAWZI A. The moderating effect of social support on the stress-satisfaction relationship among Jordanian hospital nurses. J Nurs Manag 2009;17:870-8. https://doi.org/10.1111/j.1365-2834.2009.01007.x

27. Karanikola MN, Papathanassoglou ED, Mpouzika $\mathrm{M}$, Lemonidou C. Burnout syndrome indices in Greek intensive care nursing personnel. Dimens Crit Care Nurs 2012;31:94-101. https://doi.org/10.1097/DCC.0b013e3182445fd2

28. Mooghali A, Habibi H, Ahmadi M, Habibi F. Relationship between job satisfaction and burnout among nurses in public and private hospitals in 
shiraz city in 2012. J Hospital 2015;14:120-6. (in Persian)

29. Lahana E, Papadopoulou K, Roumeliotou O, Tsounis A, Sarafis P, Niakas D. Burnout among nurses working in social welfare centers for the disabled. BMC Nurs 2017;16:15-24. https://doi.org/10.1186/s12912-017-0209-3

30. Pantenburg B, Luppa M, König H-H, RiedelHeller SG. Burnout among young physicians and its association with physicians' wishes to leave: results of a survey in Saxony, Germany. J Occup Med Toxicol 2016;11:2-11. https://doi.org/10.1186/s12995-016-0091-z

31. Elbarazi I, Loney T, Yousef S, Elias A. Prevalence of and factors associated with burnout among health care professionals in Arab countries: a systematic review. BMC Health Serv Res 2017;17:491-500. https://doi.org/10.1186/s12913-017-2319-8

32. Tremolada M, Schiavo $\mathrm{S}$, Tison $\mathrm{T}$, Sormano E, De Silvestro G, Marson P, et al. Stress, burnout, and job satisfaction in 470 health professionals in 98 apheresis units in Italy: A SIdEM collaborative study. J Clin Apher 2015;30:297-304.

https://doi.org/10.1002/jca.21379

33. Lindblom KM, Linton SJ, Fedeli C, Bryngelsson L. Burnout in the working population: relations to psychosocial work factors. Int J Behav Med 2006;13:51-9.

https://oi.org/10.1207/s15327558ijbm1301 7 


\title{
Sindrom izgaranja na poslu kod terapeuta zaposlenih $\mathbf{u}$ bolnicama različitog tipa vlasništva u Iranu
}

\author{
Ghahraman Mahmoudi ${ }^{1}$, Mohammad Ali Jahani², Masoomeh Abdi ${ }^{3}$, Sedigheh Solimanian², \\ Hossein Ali Nikbakht², Soheil Ebrahimpour ${ }^{4}$ \\ ${ }^{1}$ Istraživački centar Bolničke administracije, Ogranak sarija, Islamski univerzitet Azad, Sari, Iran \\ ${ }^{2}$ Društvene determinante istraživačkog centra, Institut za ispitivanje zdravlja, \\ Univerzitet medicinskih nauka u Babolu, Babol, Iran \\ ${ }^{3}$ Univertitet medicinskih nauka u Mazandaranu, Sari, Iran \\ ${ }^{4}$ Istraživački centar za infektivne i tropske bolesti, Institut za ispitivanje zdravlja, \\ Univerzitet medicinskih nauka u Babolu, Babol, Iran
}

\section{S A ŽETAK}

Kao složeni i multidimenzionalni problem, sindrom izgaranja na poslu dovodi do odsustvovanja, nezadovoljstva, lošeg raspoloženja, fizičke i emotivne iscrpljenosti i osećaja izmeštenosti. Cilj ove studije bilo je ispitivanje stepena izgaranja na poslu, kao i komponenti koje ga čine, u bolnicama sa različitim tipom vlasništva u Mazandaranu.

Ova deskriptivno-analitička studija sprovedena je kao studija preseka 2018. godine. Istraživanje je uključilo 2850 terapeuta koji su bili zaposleni u dvema bolnicama koje su bile nastavne baze, jednoj terapeutskoj bolnici, jednoj bolnici socijanog osiguranja, kao i jednoj privatnoj bolnici. Sve bolnice su bile smeštene u provinciji Mazandaran u Iranu. Ukupno je popunjeno 569 upitnika; kao instrument upitnika korišćena je persijska varijanta upitnika o izgaranju na poslu autorke Maslakove (MBI-eng.). Podaci su analizirani pomoću softvera SPSS 22 , primenom statističkog pristupa, pri čemu je vrednost $p<0,05$. Najviša srednja stopa emotivne iscrpljenosti zabeležena je u privatnoj bolnici $(44,69 \pm 8,50)$. U bolnici socijalnog osiguranja primećena je najviša srednja stopa depersonalizacije $(25,47 \pm 4,59)$. U vezi sa smanjenim ličnim postignućem kao komponentom, najviša stopa zabeležena je u privatnoj bolnici $(30,24 \pm 7,16)$. Najviše $i$ najniže srednje stope izgaranja na poslu zabeležene su u privatnoj bolnici $(95,48 \pm 16,71)$ i bolnicama koje su bile nastavne baze $(85,25 \pm 15,34)$. $U$ ovom pogledu postojala je značajna razlika između analiziranih bolnica $(p<0,001)$. Kako je u privatnoj bolnici zabeležena viša stopa izgaranja na poslu u poređenju sa terapeutskom bolnicom, zatim bolnicom koja je bila nastavna baza, kao i bolnicom socijalnog osiguranja, menadžeri privatne bolnice mogu se fokusirati na otklanjanje tenzija na radnom mestu, sprečavanje dugotrajnog teškog rada, kao i na nadoknađivanje smanjene isplate.

Ključne reči: izgaranje na poslu, vlasništvo, terapeuti, provincija Mazandaran, Iran 